\title{
OPTIMIZATION OF PROJECT DURATION \\ USING CPM METHOD AND MONTE CARLO CRYSTAL BALL SIMULATION
}

(Study Case Mall Laves Grand Sungkono Lagoon Building Project Surabaya)

\author{
Muhammad Chilmi \\ Faculty of Engineering \\ Civil Engineering Study Program \\ Narotama University Surabaya \\ Mchilmi26@gmail.com \\ Diah Ayu Restuti Wulandari \\ Faculty of Engineering \\ Civil Engineering Study Program \\ Narotama University Surabaya \\ diah.wulandari@narotama.ac.id
}

\begin{abstract}
There are many aspects of uncertainty on the project that affect accuracy in the process of the making project schedule, so it needs analysis of the probability of the scheduling and sensitivity of work that affects to completion total duration of the project. The existing schedule of the project Laves Mall proved was late because ignored the uncertainty aspects, by using monte Carlo crystal ball simulation will help to find completion duration of the project with the most efficiency duration, Existing completion duration project is 500 days started on 6 July 2018 to 1 December 2019, after simulation change into 604 days and the project started same as existing duration which is on 6 July 2018 to 15 March 2020 by the deviation of the duration is 104 days or about 3 months. And the highest sensitivity work activity that affects the entire duration completion of projects is cutting off of head pile cap work with sensitivity percentage is $18,8 \%$.
\end{abstract}

Keywords: Schedule and Duration of Project, CPM Method, Monte Carlo Crystal Ball.

\section{INTRODUCTION}

To anticipate uncertainty aspects in the process of making project schedule duration, Developed scheduling method that considering of the uncertainty aspects. The best way to input uncertainty aspects into the process of making project schedule duration is to analyzed in probabilistic scheduling way (Kusrianto Adi,2005). Probabilistic scheduling used a lot of method that exist or combination with any other method so get the high possibility to implemented in the real project and of course to minimalize the risk of the construction project, for the example Monte Carlo simulation. Definition of Monte Carlo simulation that written on journal by Fadjar (2008) is combination all the sampling statistic technique that used to estimate the solution of the quantitative statistic problems. On the same journal in Project Management Institute (2004) explained that in the project management, Monte Carlo simulation often used to estimating or calculating cost and duration of the project by using data that selected randomly from probability distribution of cost and duration that possibly happen with a purpose to get the efficiency result for the project. This is a common method to estimating of the probability simulation about risk aspect of the project management.

Project of Laves Mall building construction that built on land $7800 \mathrm{~m} 2$ with the length and width of a building is $120 \times 65 \mathrm{~m}$ and have 4 floors, This project is one of the project that own by PT.PP Property. Problem of the project surfaced when the progress of the work on week of $21^{\text {th }}$ delayed, The delayed can be seen on distribution of $s$ curve work progress that 
should be reach on percentage of $30,563 \%$, but realization of the work stop on percentage of $25,404 \%$ with the deviation of duration value is $-5,159 \%$ on week of $21^{\text {th }}$, actually the delayed already happen on a week of $17^{\text {th }}$ with a comparison between of work progress plan percentage and work progress realization percentage is $18,59 \%$ and $15,286 \%$ with deviation of duration value is $-3,306 \%$, however the deviation of the duration value is quite low but on the week of $21^{\text {th }}$ the deviation is less than the work plan progress and potentially could get more delayed on the next week because of that this plan was no longer relevant to used on a real implementation project, So it needs revise the planning of the existing schedule that start on the first week. The delayed cost by delivery distribution delays of material to the project. Therefore there is several methods in handling of project schedule duration, targeted of the project can run by fast duration, effective, and efficient. Base on that this research titled is "OPTIMALIZATION OF PROJECT DURATION USING CPM METHOD AND MONTE CARLO CRYSTAL BALL SIMULATION (STUDY CASE MALL LAVES GRAND SUNGKONO LAGOON BUILDING PROJECT SURABAYA)".

According to background reasearch, it can be formulated problems as follows:

1) How to applied project scheduling by Monte Carlo simulation on project of Mall Laves Grand Sungkono Lagoon building Surabaya?

2) How big the level of the success of project planned based on a time duration?

3) What is the level of sensitivity each activities on project of the construction of Mall Laves Grand Sungkono Lagoon Surabaya

4) How include risk factors and uncertainties in scheduling of construction project?

5) How response to the event that has the highest risk in construction project?

\section{LITERATURE REVIEW}

\section{Project Scheduling}

According to Ervianto (2002) Scheduling is a activity to determine time duration that needed and the order of activities and determine completion total duration of project. Project scheduling is planning phase have to translated into diagram-diagram that appropriate by time scale. Project schedule is a tool that can be used to show when each activity on going, start on, delayed or already finished. With the project schedule, is expected to use resources project can be planed or control as well. Commonly project scheduling divided into 2 types as follows:

1) Deterministic scheduling : The network of interconnected with dependencies describing works to be performed, Working time and plan completion of projects. Each activities has duration planed. Deterministic scheduling divide into 2 types as follows :

- CPM (Critical Path Method) : Arrow Diagram, Time Scale Diagram, dan Precedence Diagram Method (PDM)

- Non-CPM : Bar/Gantt Chart, Line Diagram

2) Probabilistic scheduling : The network with all the element of deterministic scheduling plan, however tetapi the period of the assignment is random variabel-variabel. Example from this probabilistic scheduling is : PERT dan Montecarlo (Husen.A,2010).

\section{Monte Carlo Simulation}

Monte Carlo Simulation is is combination all the sampling statistic technique that used to estimate the solution of the quantitative statistic problems Fadjar (2008). (Project Management Institue, 2004), explained that in the project management, Monte Carlo simulation often used to estimating or calculating cost and duration of the project by using data that selected randomly from probability distribution of cost and duration that possibly happen with a purpose to get the efficiency result for the project. 
If a system containing elements that follow factors of the possibility, model that used to The

\begin{tabular}{|c|c|}
\hline RISK & UNCERTAINTY \\
\hline
\end{tabular}

model used is Monte Carlo simulation model. Base of the Monte Carlo Simulation is element of trial using random sample. In the project management, Monte Carlo simulation can estimate the affect of risk and uncertainty of the project schedule and budgeting, so by providing project manager a statistic indicator of the project performance, are like target completion of duration and budgeting project (Kakiay,2004).

The Advantages using of the Monte Carlo simulation on the project is Monte Carlo simulation is that quite enough excellent tool that can analyzed and understanding and estimating the potential aspects of uncertainty project. Without using any consideration of the uncertainty on a project schedule and budgeting, project manager should placed himself into the risk that can be over the target of the project. Monte Carlo simulation helps project manager into addition and justification project based on the agreement, With risk event that will happen during the project. The other advantages of using Monte Carlo simulation is the another way in analysis project with combining uncertainties. (Kakiay 2004).

\section{Probability Teory}

Basically probability tory is reviews and measuring uncertainty and trying to describe quantitatively. Like an activity that happen repeatedly with a condition With the condition of being regarded as the same (Soeharto, 1995). Assumption three duration of activity on the CPM using statistic analysis to determine the formulation. First assumption that duration of CPM is normal distribution function, in this case Beta distribution function, so the probability it the same way that is continous probability distribution.

The research uses data from the results of field research. The data obtained first formed in the statistical data, for example is the arc of normal distribution that appropriate with PERT teory, That all the duration of related and the determination of every continous probability distribution that not every duration.

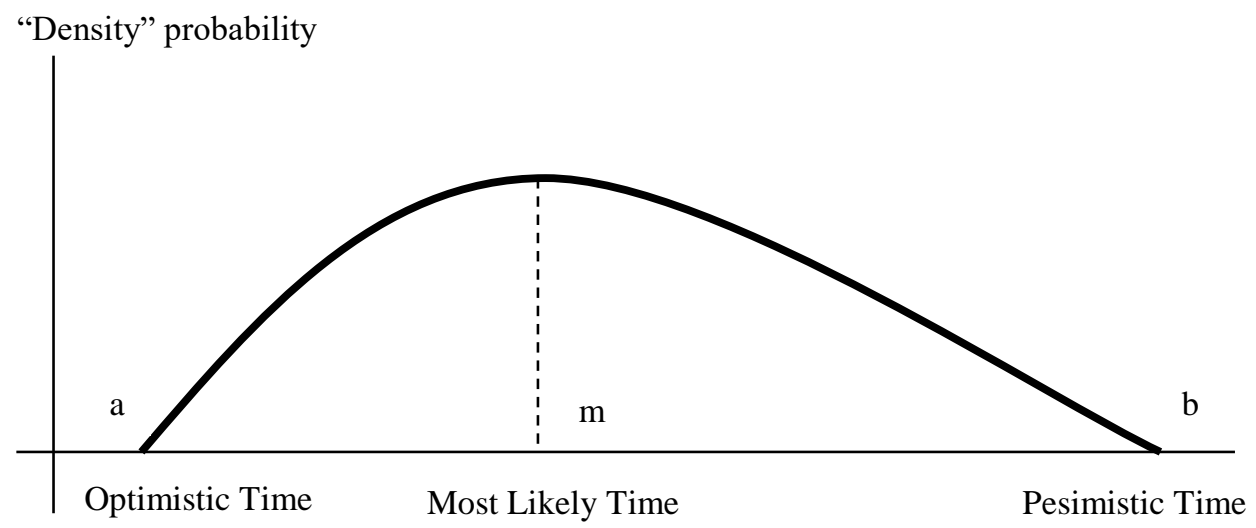

Figure 1 Distribution of curve asymmetry (beta) dengan $a, m$, dan $b$

\section{Risk And Uncertainty}

Uncertainty in general are defined by a state where the information given not strong enough about understanding or knowledge related to a the occurrence /, activities the impact, and the possibility of.As has been didefinsikan by djohanputro ( 2004 ), uncertainty ( uncertainty ) details can be defined with the situation where there is some of the possibility of and every movement will cause a different result, but the possibilities or probablitas the incident itself unknown quantitatively

Of risks and the uncertainty it actually has the difference the characteristics and character of a clear. Are the main table the comparison between risk and uncertainty according to Djohanputro (2004): 


\begin{tabular}{|c|c|}
\hline Subject having quantity & Subject did not have the quantity \\
\hline Known the probability it happens & It cannot be known the probability it happens \\
\hline $\begin{array}{c}\text { There is the supporting data about } \\
\text { the possibility it happened }\end{array}$ & $\begin{array}{c}\text { There is no the supporting data for measuring the } \\
\text { possibility of it happens }\end{array}$ \\
\hline
\end{tabular}

Risk in activities simple or in consume. not be able to avoided included in execution activities of development projects in decision-making realized that or not, Will based on the impact of various risk factors good and uncertainty that led to the banyanya the possibility or probability in project. The following are several the causes of uncertainty :

- The information is incomplete: information qualitative and quantitative information that is overcrowded would prevent decision makers to recognize the problem and delay effective decisions.

- This problem is not clear: this can lead to a lack of confidence in making a decision due to the trouble in the formulation of a problem into some components would have understood.

- Not capable of identifying the alternative solution: if there is difficulty in identifying a problem and alternative solutions, components the decision maker allows policy makers to choose the best decisions or fatal

\section{RESEARCH METHODOLOGY}

\section{Project Data}

The research was conducted standard on projects of the construction of mall laves grand sungkono lagoon which is located at JL.KH Abdul Wahab Siamin Dukuh Pakis, Surabaya City East Java. The duration of the project exsiting is 500 day project starts on the staircase 7 july 2018 end in the december 2020. 1The primary data obtained from of the process a questioner with organizers of the project in this case pt.pp contractor for the taking of the bottom of the number of as follows :

$\mathrm{n}=\mathrm{N} /(\mathrm{N} \cdot \mathrm{d} 2+1)$

Note :

(n) = The number of a questionnaire will be distributed

(N) = The number of the population based on criteria chosen (previous project of mall building is 4 ) project

(d2) = The coefficient accuracy of the questionnaire was chosen 005 So the conclusion are :

$n=4 /(4 \cdot 0,052+1)=4 / 1,01=3,96$ Rounded to 4 questionnaires will be distributed

\section{Analyzing Data}

The duration of which were found the primary data in the form of 4 duration which are ( duration plan ( tr ), optimistic time ( to ) duration, duration pessimistic time of , and duration of most likely time ( $\mathrm{tm})$ ). Then counting in duration total completion of projects by inserting data into a network of has already been prepared beforehand so that the total duration and hedges or critical work.

\section{Simulation Data}

After the critical line and 4 duration arranged in one data, namely start next Monte Carlo simulation .Work was chosen to do work in the simulation is only lane just critical, then every work considered to have the distribution of triangle with so will wait till next week tone a lower limit the middle and the end so that data that would be included into the simulation is only just data the questionnaire.

\section{Result of Simulation}

After all the simulation was done, report or the distribution of a triangular any work and the level of sensitivity work influences duration. completion of projects. In distribution triangular 
data duration taken is data to percentile $50 \%$ (because regarded as duration most often / favored). Then after the data of every work taken then, rewrite network based on data, Monte Carlo simulation so get output report in the form of a curve s comparison between duration after simulation of plans and duration.

\section{Data Duration}

\section{RESULT AND DISCUSSION}

Here is an arrangement of the employment data mixed critical data with the simulation Monte Carlo with the help of crystal ball as follows :

Table 2 The result of Monte Carlo simulation of Critical Line (Source by calculated)

\begin{tabular}{|c|c|c|c|c|c|c|c|c|c|c|}
\hline \multirow[b]{2}{*}{ No } & \multirow[b]{2}{*}{ Activities } & \multicolumn{2}{|c|}{ Existing Duration } & \multicolumn{3}{|c|}{ Average Survey Duration } & \multirow{2}{*}{$\begin{array}{c}\text { Te } \\
(a+4 m+b) / 6\end{array}$} & \multirow[b]{2}{*}{$\begin{array}{c}\text { Duration } \\
\text { Used }\end{array}$} & \multirow{2}{*}{$\begin{array}{l}\text { Simulation } \\
\text { Duration }\end{array}$} & \multirow{2}{*}{$\begin{array}{c}\text { Final } \\
\text { Duration }\end{array}$} \\
\hline & & Week & Day & $\begin{array}{c}\text { Optimistic } \\
\text { (to) }\end{array}$ & $\begin{array}{c}\text { Most Likely } \\
\text { (tm) }\end{array}$ & $\begin{array}{c}\text { Pesimistic } \\
\text { (tp) }\end{array}$ & & & & \\
\hline 1 & PRELIMINARY & 71 & 500 & 506 & 694 & 826 & 684,667 & 684,667 & 604 & 604 \\
\hline 4 & Pekerjaan Lain-Lain & 10 & 67 & 70,650 & 97,200 & 119,475 & 96,488 & 96,488 & 96,515 & 97 \\
\hline 5 & PEKERJAAN STRUKTUR & & & & & & - & & & \\
\hline 6 & Pekerjaan Lantai Basement 3 & & & & & & - & & & \\
\hline 7 & Pekerjaan Pile Cap Lt.B3 & 7 & 50 & 42,888 & 56,563 & 71,475 & 56,769 & 56,769 & 56,605 & 57 \\
\hline 8 & Pekerjaan Tie Beam Lt.B3 & 7 & 47 & 44,115 & 60,005 & 75,295 & 59,905 & 59,905 & 59,94 & 60 \\
\hline 9 & Pekerjaan Slab Lt.B3 & 5 & 32 & 29,540 & 47,380 & 61,360 & 46,737 & 46,737 & 46,374 & 47 \\
\hline 10 & Pekerjaan Kolom Lt.B3 & 3 & 17 & 20,200 & 34,558 & 35,770 & 32,367 & 32,367 & 30,821 & 31 \\
\hline 14 & Pekerjaan Lantai Basement 2 & & & & & & - & & & \\
\hline 15 & Pekerjaan Balok \& Drop Panel Lt.B2 & 4 & 25 & 22,688 & 31,175 & 37,963 & 30,892 & 30,892 & 30,767 & 31 \\
\hline 16 & Pekerjaan Slab Lt.B2 & 4 & 25 & 22,688 & 31,175 & 37,963 & 30,892 & & & 25 \\
\hline 17 & Pekerjaan Kolom Lt.B2 & 2 & 15 & 17,125 & 24,025 & 30,150 & 23,896 & 23,896 & 24,012 & 25 \\
\hline 18 & Pekerjaan Ramp Lt.B2 & 2 & 15 & 17,125 & 24,025 & 30,150 & 23,896 & 23,896 & 23,925 & 24 \\
\hline 20 & Pekerjaan Lantai Basement 1 & & & & & & - & & & \\
\hline 21 & Pekerjaan Balok \& Drop Panel Lt.B1 & 4 & 25 & 22,688 & 31,175 & 37,963 & 30,892 & 30,892 & 30,819 & 31 \\
\hline 22 & Pekerjaan Slab Lt.B1 & 4 & 25 & 22,688 & 31,175 & 37,963 & 30,892 & 30,892 & 30,784 & 31 \\
\hline 23 & Pekerjaan Kolom Lt.B1 & 2 & 15 & 17,125 & 24,025 & 30,150 & 23,896 & 23,896 & 24,049 & 25 \\
\hline 24 & Pekerjaan Ramp Lt.B1 & 2 & 15 & 17,125 & 24,025 & 30,150 & 23,896 & 23,896 & 23,775 & 24 \\
\hline 26 & Pekerjaan Lower Ground & & & & & & - & & & \\
\hline 27 & Pekerjaan Balok \& Drop Panel Lt.LG & 4 & 25 & 22,688 & 31,175 & 37,963 & 30,892 & 30,892 & 30,812 & 31 \\
\hline 28 & Pekerjaan Slab Lt.LG & 4 & 25 & 22,688 & 31,175 & 37,963 & 30,892 & 30,892 & 30,661 & 31 \\
\hline 29 & Pekerjaan Kolom Lt.LG & 2 & 15 & 17,125 & 24,025 & 30,150 & 23,896 & 23,896 & 23,949 & 24 \\
\hline 30 & Pekerjaan Ramp Lt.LG & 2 & 15 & 17,125 & 24,025 & 30,150 & 23,896 & 23,896 & 23,877 & 24 \\
\hline 32 & Pekerjaan Lantai Ground & & & & & & - & & & \\
\hline 33 & Pekerjaan Pile Cap Lt.GF & 4 & 25 & 22,688 & 31,175 & 37,963 & 30,892 & 30,892 & 30,738 & 31 \\
\hline 34 & Pekerjaan Tie Beam Lt.GF & 4 & 25 & 22,688 & 31,175 & 37,963 & 30,892 & 30,892 & 30,939 & 31 \\
\hline 35 & Pekerjaan Slab Lt.GF & 4 & 25 & 22,688 & 31,175 & 37,963 & 30,892 & 30,892 & 30,661 & 31 \\
\hline 36 & Pekerjaan Kolom Lt.GF & 2 & 15 & 17,125 & 24,025 & 30,150 & 23,896 & 23,896 & 23,561 & 24 \\
\hline 38 & Pekerjaan Lantai 2 & & & & & & - & & & \\
\hline 39 & Pekerjaan Balok \& Drop Panel Lt. 2 & 4 & 25 & 22,688 & 31,175 & 37,963 & 30,892 & 30,892 & 30,704 & 31 \\
\hline 40 & Pekerjaan Slab Lt. 2 & 4 & 25 & 22,688 & 31,175 & 37,963 & 30,892 & 30,892 & 30,862 & 31 \\
\hline 41 & Pekerjaan Kolom Lt.2 & 2 & 15 & 17,125 & 24,025 & 30,150 & 23,896 & 23,896 & 23,886 & 24 \\
\hline 43 & Pekerjaan Lantai 3 & & & & & & - & & & \\
\hline 44 & Pekerjaan Balok \& Drop Panel Lt. 3 & 4 & 25 & 22,688 & 31,175 & 37,963 & 30,892 & 30,892 & 30,544 & 31 \\
\hline 45 & Pekerjaan Slab Lt. 3 & 4 & 25 & 22,688 & 31,175 & 37,963 & 30,892 & 30,892 & 30,876 & 31 \\
\hline 46 & Pekerjaan Kolom Lt.3 & 2 & 15 & 17,125 & 24,025 & 30,150 & 23,896 & 23,896 & 23,885 & 24 \\
\hline 48 & Pekerjaan Lantai 4 & & & & & & - & & & \\
\hline 49 & Pekerjaan Balok \& Drop Panel Lt.4 & 4 & 25 & 22,688 & 31,175 & 37,963 & 30,892 & 30,892 & 30,72 & 31 \\
\hline 50 & Pekerjaan Slab Lt.4 & 4 & 25 & 22,688 & 31,175 & 37,963 & 30,892 & 30,892 & 30,89 & 31 \\
\hline 51 & Pekerjaan Kolom Lt.4 & 2 & 15 & 17,125 & 24,025 & 30,150 & 23,896 & 23,896 & 23,966 & 24 \\
\hline 53 & Pekerjaan Lantai $4 \mathrm{Mz}$ & & & & & & - & & & \\
\hline 54 & Pekerjaan Balok \& Drop Panel Lt.4 Mz. & 3 & 19 & 20,860 & 30,125 & 37,128 & 29,748 & 29,748 & 29,434 & 30 \\
\hline 56 & Pekerjaan Lantai 5 & & & & & & - & & & \\
\hline 57 & Pekerjaan Balok \& Drop Panel Lt.5 & 3 & 19 & 20,860 & 30,125 & 37,128 & 29,748 & 29,748 & 29,642 & 30 \\
\hline 58 & Pekerjaan Slab Lt.5 & 3 & 19 & 20,860 & 30,125 & 37,128 & 29,748 & 29,748 & 29,289 & 30 \\
\hline 59 & Pekerjaan Kolom Lt.5 & 2 & 15 & 17,125 & 24,025 & 30,150 & 23,896 & 23,896 & 23,795 & 24 \\
\hline 60 & Pekerjaan Tangga Lt.5 & 2 & 12 & 11,280 & 15,608 & 18,983 & 15,449 & 15,449 & 15,406 & 16 \\
\hline 61 & Pekerjaan Lantai Atap (Watertank) & & & & & & - & & & \\
\hline 62 & Pekerjaan Balok \& Drop Panel Lt.Atap & 2 & 15 & 17,625 & 24,213 & 30,088 & 24,094 & 24,094 & 24,118 & 25 \\
\hline 184 & Pekerjaan Transportasi Dalam Gedung & & & & & & - & & & \\
\hline 185 & Lift & 9 & 60 & 52,000 & 73,425 & 89,850 & 72,592 & 72,592 & 72,522 & 73 \\
\hline
\end{tabular}




\section{Counting the Distribution of Completion of Projects}

In the determination of the duration of the projects could be as a whole can be obtained in two ways as follows :

\section{Counting in duration total on the critical line and has simulated}

In this way total duration can be found first recording the duration of the simulation any work on the critical and duration of existing from other jobs that were not included in a critical and input into existing network use some help software ms. project so that the duration of total and end date of a settlement project will arise and can be used as a result of the distribution of the total all the work on projects

After data on data based on the duration of the work on the critical of simulation and duration of existing duration so next insert data into ms.project network and duration of the total for the duration of the project of 604500 the previous day .The project commenced on september 6 july 2018 and ends on 14 march disimulasi after 2020.

\section{Counting duration total base on $\mathbf{3}$ parameter of duration}

By means of this second duration total project was obtained through the completion of a job means analyzes 3 parameter duration of the survey duration . The duration of 3 parameter in the area are duration are optimistic that, the duration of pessimistic and duration of most likely our foremost / .An example is the work of the preliminary work taken because this job in should start with at the beginning of the project and berkahir until the project finished, so that the simulation monte carlo or as follows :

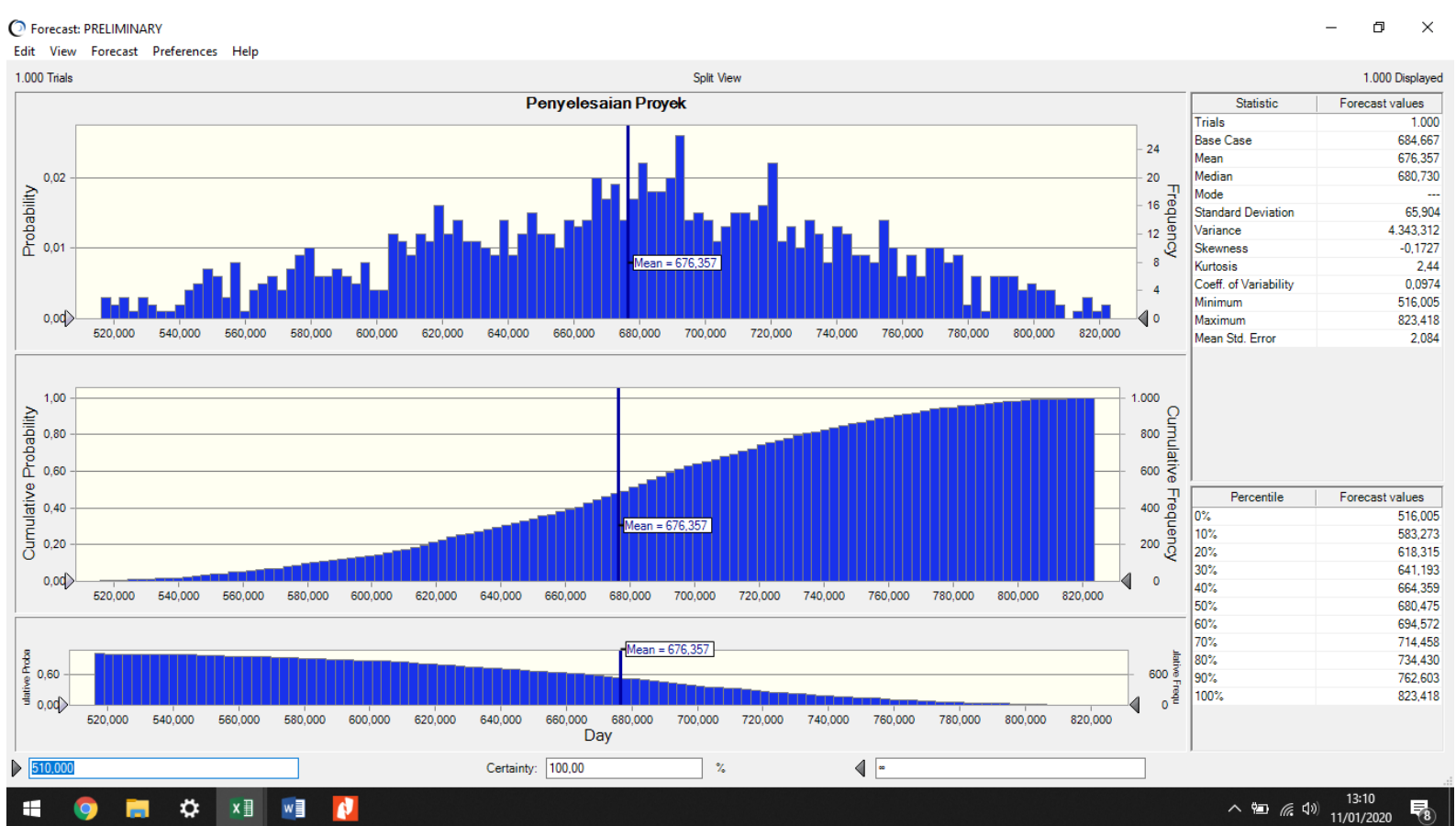

Figure 2 The result of Monte Carlo Simulation from total completion project (Source by own calculated) 
The results of a simulation monte carlo in duration to an estimation of the completion of projects the construction of mall laves grand sungkono lagoon surabaya obtained as follows :

\begin{tabular}{|l|r|}
\hline Percentile & Forecast values \\
\hline $0 \%$ & 516,005 \\
\hline $10 \%$ & 583,273 \\
\hline $20 \%$ & 618,315 \\
\hline $30 \%$ & 641,193 \\
\hline $40 \%$ & 664,359 \\
\hline $50 \%$ & 680,475 \\
\hline $60 \%$ & 694,572 \\
$70 \%$ & 714,458 \\
\hline $80 \%$ & 734,430 \\
$90 \%$ & 762,603 \\
\hline $100 \%$ & 823,418 \\
\hline
\end{tabular}

Figure 3 Result of Monte Carlo Simulation in Percentile (Source by own calculated)

- $\mathrm{P} 10 \%=583,273---584$ days

P $10 \%$ represent the value of optimistic completion of projects but with probabilities frequency persentil completion of projects $1-10 \%$ for applied and not this value to be elected as a total duration completion of projects.

- $P 50 \%=680,475---681$ days

P $50 \%$ represent the value of most likely time of completion of projects with probabilities percentile frequency completion of projects $41-50 \%$ or in other words on average the value of who is used frequently, so that this value that was to become the total duration of the completion of the project because of should be duration completion of projects be between corridor duration are optimistic and most likely. So that the beginning of the project or start on july 6 and an end to project upon on 31 may 2020 of the total duration of 681 the day of completion of projects.

- $P 90 \%=762,603$--- 763 days

P $90 \%$ represent the value of the total distribution pessimistic outlook by the completion of projects with probabilities percentile frequency completion of projects $81-90 \%$ because the duration of the total which is too long that can be led to a loss in burden project so the value is taken as the duration of total completion of projects.

\section{The level of the sensitivity of project activities}

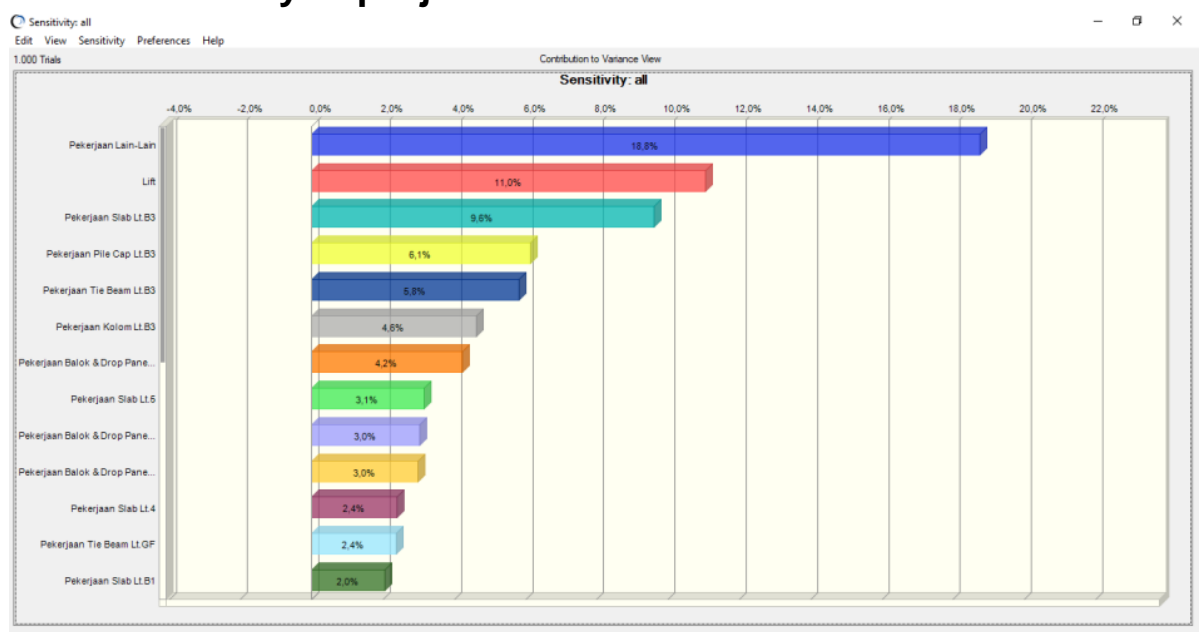


Figure 4 The result of recap Monte Carlo Simulation by critical line (Source by own calculated)

Based on analysis of the sensitivity ( sensitivy chart), then aktivitas-aktivitas that have substantial implications on duration project: work structure ( as work column , beam , tie beam , a slab ) and earthwork ( as urug sirtu (perapihan and compaction ) and cutting pile ) foundation and work elevator influences mobilization project.

\section{CONCLUSION}

Based on this study which was conducted, a conclusion to the research done by these chareges in the future as follows:

1. Based on the results obtained distibusi monte carlo simulation time variations settlement building construction project mall laves grand sungkono 2 lagoon with the different outcomes:

- Settled with a first for the duration of the time 604 day with existing 500 the previous duration, project commenced on may 6 july 2018 ending after in simulated on may 14 march 2020 with existing the settlement date earlier on june 1 december 2019 with deviation 104 time of day

- In the manner of a simulation first obtained the results of the duration of the completion of the time of day with existing 681 previous duration 500 the day, the project commenced on july 6 in 2018 ending after simulation on 31 may 2020 with existing the settlement date earlier in on december 1st 2019 with deviation of 181 days time

2. The completion of projects or with 2 a manner at variance with the success rate of percent for the duration of 38\% 60450 day and percent for the duration of 681 days, but because deviation time with the second way too far and chosen to optimize the completion of projects is duration with didaptkan by means of which is first 604 day because timing is still in corridor between optimistic time and most likely time.

3. The sensitivity to the order of the effects of the largest to smallest as follows :

- Work of Lain-Lain/Tanah (Cutting of the head of bore pile) $18,8 \%$

- Work of Lift $11,00 \%$

- Work of Slab Lt.B3 9,6\%

- Work of Pile Cap Lt.B3 6,1\%

- Work of Tie Beam Lt.B3 5,8\%

- The other activities under $5 \%$

4. Work by sensitivity high and potentially slow duration completion of projects also has risk factors and uncertainty, the following are risk work by sensitivity high from the simulation sensitivity work that is :

Table 3 The risk of work by rate of sensitivity

\begin{tabular}{|c|l|l|}
\hline No & \multicolumn{1}{|c|}{ Work } & \multicolumn{1}{c|}{ Risk } \\
\hline 1 & $\begin{array}{l}\text { Cutting of the head of } \\
\text { Bore Pile Work }\end{array}$ & $\begin{array}{l}\text { If the cutting head of pile is not neat and bore pile is not } \\
\text { enough long is cut off , so will be reduced powers of grip clip } \\
\text { the foundation in pile cap. }\end{array}$ \\
\hline 2 & $\begin{array}{l}\text { Lift and Elevator } \\
\text { Work }\end{array}$ & $\begin{array}{l}\text { The power of the mast and beam buffer zones should be } \\
\text { strong enough and placed on the bond of the position of } \\
\text { structure building proper if not gonna happen failure bracing } \\
\text { and could have happened off. }\end{array}$ \\
\hline
\end{tabular}




\begin{tabular}{|c|l|l|}
\hline 3 & Slab Work & $\begin{array}{l}\text { Bekesting slab on the edges of having to close in meetings } \\
\text { and there is only room for drainage if not the only concrete } \\
\text { slab will not uniformly so can there be a slab of if it is dry } \\
\text { resulting in reduced power as a slab of retaining and } \\
\text { channeling the building. }\end{array}$ \\
\hline 4 & Pile Cap Work & $\begin{array}{l}\text { Thickness and dimension pile cab different need calculation } \\
\text { that is ripe and careful because any area of which is attached } \\
\text { pile cab bear larger the burden on different each other. }\end{array}$ \\
\hline 5 & Tie Beam Work & $\begin{array}{l}\text { Tie beam that will be installed as a bond pile cab with each } \\
\text { other memperhattikan high elevation to the ground it would } \\
\text { be very influential on the curvature of a beam and led to not } \\
\text { burden from the building. }\end{array}$ \\
\hline
\end{tabular}

\section{Suggestion}

Based on the results of the analysis obtained from the preparation of this research , feedback as follows :

1. If this research is continued assistance will be better if using software primavera because output data generated will be more detail than used microsoft project

2. In scheduling a probabilistic it would be better if using historical data is complete and the data much so the results will be more accurate, in addition the selection of data should be more selective in accordance any condition of a job.

3. Existing scheduling actually has not deemed the value of the probability so that delays in not biased measured at the beginning has been proven by the determination of the duration of existing who overly optimistic so that have experienced delays

\section{REFERENCES}

[1] Djohanputro, Bramantyo. Manajemen Resiko Korporat Terintegrasi, PPM, p14. 2004.

[2] Fadjar, A. Aplikasi Simulasi Monte Carlo dalam Estimasi Biaya Proyek. Jurnal SMARTek. 6(4):222-227. 2008

[3] Kerzner, Harold. Project Management : A System Approach to Planning Schedulling and Controlling, Van Nostrand Reinhold.1995.

[4] Kusrianto, Adi. Panduan Lengkap Memakai Microsoft Project 2003. Jakarta: Penerbit PT Elex media Komputindo. 2005.

[5] Project Management Institute. A Guide to the Project Management Body of Knowledge: PMBOK Guide. $3^{\text {rd }}$ ed. Newton Square.Pennsylvania: Project Management Institute. 2004.

[6] Soeharto. I. Manajemen Proyek dari Konseptual sampai Operasional Jilid 2. Jakarta : PT. Gelora Aksara Pratama. 1997. 